\title{
Differential Regulation of Right and Left Ventricular $\beta$-Adrenergic Receptors in Newborn Lambs with Experimental Cyanotic Heart Disease
}

\author{
Daniel Bernstein, Ellen Voss, Sheila Huang, Rahul Doshi, and Charlie Crane \\ With the technical assistance of Rebecca Peters \\ Department of Pediatrics, Stanford University, Stanford, California 94305
}

\begin{abstract}
To determine whether chronic hypoxemia secondary to an intracardiac right-to-left shunt alters regulation of the myocardial $\beta$-adrenergic receptor/adenylate cyclase system, we produced chronic hypoxemia in nine newborn lambs by creating right ventricular outflow obstruction and an atrial septal defect. Oxygen saturation was reduced to $65-74 \%$ for 2 wk. Eight lambs served as normoxemic controls. $\beta$-receptor density $\left(B_{\max }\right)$ and ligand affinity $\left(K_{\mathrm{D}}\right)$ were determined with the radioligand $\left[{ }^{125}\right.$ I]iodocyanopindolol and adenylate cyclase activity determined during stimulation with isoproterenol, sodium fluoride (NaF), and forskolin. During chronic hypoxemia, $B_{\max }$ decreased $45 \%$ (hypoxemic, $180.6 \pm 31.5$ vs. control, $330.5 \pm 60.1 \mathrm{fmol} / \mathrm{mg}$ ) in the left ventricle (exposed to hypoxemia alone) but was unchanged in the right ventricle (exposed to hypoxemia and pressure overload). $K_{\mathrm{D}}$ was not different from control in either ventricle. Left ventricular isoproterenolstimulated adenylate cyclase activity was decreased by $39 \%$ (30.0 $\pm 4.3 \%$ increase vs. $44.1 \pm 9.5 \%$ increase) whereas right ventricular adenylate cyclase activity was unchanged. Stimulation of adenylate cyclase with $\mathrm{NaF}$ or forskolin was not different from control in either ventricle. Circulating epinephrine was increased fourfold whereas circulating and myocardial norepinephrine were unchanged. These data demonstrate a downregulation of the left ventricular $\beta$-adrenergic receptor/adenylate cyclase system during chronic hypoxemia secondary to an intracardiac right-to-left shunt. (J. Clin. Invest. 1990. 85:6874.) cyanotic heart disease $\bullet$ hypoxemia $\bullet$ myocardial $\beta$-adrenergic receptor regulation
\end{abstract}

\section{Introduction}

The sympathetic nervous system plays a major role in the cardiovascular adaptations to both acute and chronic hypoxemia. During acute hypoxemia, sympathetic stimulation increases heart rate and cardiac output and thus serves to maintain systemic oxygen delivery $(1,2)$. During chronic hypoxemia, such as occurs in infants and children with cyanotic congenital heart disease, additional compensations, such as polycythemia, allow cardiac output to return to normal. There

This study was presented in part at the Annual Meeting of the Society for Pediatric Research, Washington, DC, May 1988, and published in abstract form (1988. Pediatr. Res. 23:216A).

Address reprint requests to Dr. Bernstein.

Received for publication 28 November 1988 and in revised form 8 August 1989.

J. Clin. Invest.

(c) The American Society for Clinical Investigation, Inc.

$0021-9738 / 90 / 01 / 0068 / 07 \quad \$ 2.00$

Volume 85, January 1990, 68-74 is, however, evidence to suggest that the increase in sympathetic tone persists (3-5). Thus, when hypoxemia is prolonged, the benefits of increased sympathetic stimulation may be outweighed by its deleterious cellular, metabolic, and circulatory effects $(2,6-8)$. One potential cellular-level consequence of chronic sympathetic stimulation is a down-regulation of the $\beta$-adrenergic receptor/adenylate cyclase system, as occurs in patients with heart failure secondary to cardiomyopathy ( 9 , 10). If present during chronic hypoxemia, this down-regulation could contribute to the decrease in myocardial performance and reserve that has been demonstrated in patients with cyanotic congenital heart disease $(11,12)$.

Previous studies of $\beta$-adrenergic receptor/adenylate cyclase regulation during chronic hypoxemia have been limited to models of chronic alveolar hypoxemia (13-15). These data, simulating high-altitude exposure, may fail to account for the additional hemodynamic derangements which occur in conjunction with chronic hypoxemia in infants and children with cyanotic congenital heart defects (16). The importance of choosing a model of chronic hypoxemia relevant to this specific clinical state is demonstrated by the divergent findings of $\beta$-receptor down-regulation in heart failure secondary to cardiomyopathy $(9,10)$ vs. up-regulation in heart failure secondary to pressure overload hypertrophy (17). Previous studies have also failed to examine the differential effects of hypoxemia and structural heart defects on $\beta$-receptor regulation in both the left and right ventricles and have not correlated alterations in $\beta$-receptor density with simultaneous measurements of sympathetic activity. Furthermore, all previous studies have used adult models, and thus have not accounted for developmental differences in cardiopulmonary and sympathetic nervous system function in the newborn which might alter the cellular response to hypoxemia (18-20).

The purpose of the current study was to investigate myocardial $\beta$-adrenergic receptor regulation in a model of cyanotic congenital heart disease in the newborn lamb. We sought to determine: ( $a$ ) whether the myocardial $\beta$-adrenergic receptor is down-regulated when chronic hypoxemia occurs secondary to an intracardiac right-to-left shunt; $(b)$ whether a difference occurs in $\beta$-receptor regulation between the right (exposed to hypoxemia and pressure overload) and left (exposed to hypoxemia alone) ventricles; $(c)$ whether alterations in $\beta$-receptor density were biochemically relevant, given the redundancy and amplification inherent in the $\beta$-receptor/adenylate cyclase system; and $(d)$ whether $\beta$-receptor down-regulation is associated with alterations in either circulating catecholamines $(4$, $21)$ or in thyroid hormone $(22,23)$.

\section{Methods}

Preparation. Chronic hypoxemia was produced in nine newborn lambs using a model of cyanotic congenital heart disease developed by Teitel and co-workers (3). Briefly, surgery was performed on newborn 
lambs of mixed western breed during the first week of life. Polyvinyl catheters were inserted via a hind leg pedal artery and vein and advanced into the descending aorta and inferior vena cava. Under general anesthesia a thoracotomy was performed in the fourth left intercostal space. Polyvinyl catheters were inserted into the ascending aorta, superior vena cava, right ventricle, pulmonary artery, and left atrium. A No. 5 F Fogarty dilation catheter (American Edwards Laboratories, Irvine, CA) was inserted via the hind leg pedal vein and advanced by direct visualization into the left atrium. A balloon atrial septostomy was then performed. Next, an inflatable silicone rubber balloon occluder with polyvinyl tubing was placed around the main pulmonary artery. This bailoon occluder was left deflated during the immediate postoperative period and in this state was nonrestrictive. All catheters were filled with heparin, plugged, and brought to the skin via a subcutaneous tunnel and were protected by a zippered vest worn by the lamb. The lambs were then returned to their cages and bottle fed with Land O'Lakes Lamb Milk Replacer (Land O'Lakes, Arden Hills, MN), supplying $0.9 \mathrm{cal} / \mu \mathrm{l}$, throughout the study period. The volume and frequency of feedings were: $475 \mu \mathrm{l}$ daily in six separate feedings from the first to the third days of life, $710 \mu \mathrm{l}$ daily in three feedings up to 2 wk, and then ad lib quantities in three daily feedings afterwards. The intravascular catheters were flushed with saline and reheparinized daily during the 2 wk study period. Antibiotics (Dual-Pen, Tech America, Kansas City, MO) were given intramuscularly immediately before each catheter flushing. Intramuscular iron dextran complex (equivalent to $100 \mathrm{mg}$ of elemental iron) was given weekly to avoid the hemodynamic effects of iron deficiency.

After the lambs recovered for three days, hypoxemia was produced by gradually inflating the pulmonary arterial occluder balloon with saline, which partially obstructed the right ventricular outflow tract and induced atrial right-to-left shunting. The details of this gradual inflation procedure have been described previously (3). By adjusting the degree of balloon inflation, aortic oxygen saturation (measured by an OSM3 hemoximeter, Radiometer, Copenhagen) was decreased to 65-74\% and was maintained at this level for $2 \mathrm{wk}$. Eight additional lambs also underwent thoracotomies and catheter placement but did not have atrial septostomies or balloon occluder placement and served as normoxemic controls. The control lambs were housed and fed in a manner identical to that of the hypoxemic lambs. Although the lambs were not pair-fed, we have previously shown that oral intake is the same in chronically hypoxemic and control lambs (24).

At the end of the study the lambs were killed with intravenous pentobarbital $(90 \mathrm{mg} / \mathrm{kg}$ ) and the hearts were immediately removed. The heart was separated into right and left ventricular free walls, septum, and atria, and each part was weighed. Because of the wide variability in the sizes of the lambs, right and left ventricular free wall weights were normalized by dividing by total body weight. Right ventricular free wall to left ventricular free wall weight ratios were also calculated.

$\beta$-Adrenergic receptor assay. Samples of myocardium were taken from the mid right and left ventricular free walls. Thin layers (approximately $1 \mathrm{~mm}$ ) of epicardium and endocardium were dissected free and discarded and the tissue samples frozen at $-70^{\circ} \mathrm{C}$. $\beta$-adrenergic receptor density was determined utilizing [ ${ }^{125}$ I] ${ }^{2}$ iodocyanopindolol (ICYP) ${ }^{1}$ (10). Approximately $150 \mathrm{mg}$ of each tissue sample was placed in icecold buffer ( $10 \mathrm{mM}$ Tris base, $1 \mathrm{mM}$ EGTA) and homogenized with a Polytron (Brinkmann Instruments Co., Westbury, NY). $1 \mathrm{ml}$ of $2.5 \mathrm{M}$ $\mathrm{KCl}$ was added to the homogenate, which was stirred at $4^{\circ} \mathrm{C}$ for 15 min. Another $1.0 \mathrm{ml}$ Tris-EGTA buffer was added and the sample was centrifuged at $50,000 \mathrm{~g}$ for $15 \mathrm{~min}$ at $4^{\circ} \mathrm{C}$ to pellet the sarcolemmal membrane. This pellet was resuspended in $6.0 \mathrm{ml}$ buffer $(20 \mathrm{mM}$ Tris base, $150 \mathrm{mM} \mathrm{NaCl}$ ) and washed three times in this manner. The final pellet was suspended in $5.7 \mathrm{ml}$ of buffer and homogenized thoroughly before being filtered through four layers of gauze. Additional buffer

1. Abbreviations used in this paper: ICYP, iodocyanopindolol. was poured through the gauze to rinse it, bringing the final homogenate to a concentration of $7.5-10 \mathrm{mg}$ of tissue per milliliter.

The assays were performed in triplicate by incubating $300 \mu \mathrm{l}$ of sarcolemmal homogenate with increasing concentrations (6.25-450 pM) of ICYP (specific activity $\approx 2,200 \mathrm{Ci} / \mathrm{mmol}$, New England Nuclear, Boston, MA). Nonspecific binding was determined by the addition of $10^{-6} \mathrm{M} \mathrm{L}$-propranolol to one set of assay tubes. This concentration of propranolol was chosen based on competition binding studies with varying concentrations of propranolol to avoid binding to specific nonreceptor or nonspecific sites at higher concentrations $(25$, 26). The assay was then incubated for $2 \mathrm{~h}$ at $37^{\circ} \mathrm{C}$, quickly vacuumfiltered through 1- $\mu \mathrm{m}$ GF/C glass-fiber filters (Gelman Sciences, Inc., Ann Arbor, MI) in an M-24R cell harvester (Brandel, Gaithersburg, MD) and rinsed four times with $5.0 \mathrm{ml}$ of $20 \mathrm{mM}$ Tris $/ 150 \mathrm{mM} \mathrm{NaCl}$ buffer. When the filters were dry they were placed in plastic tubes for counting in a gamma counter (United Technologies Packard, Downers Grove, IL). The remaining homogenate was frozen at $-70^{\circ} \mathrm{C}$ for protein analysis by the method of Lowry et al. (27). Specific binding was calculated as the total number of ICYP counts minus ICYP counts in the presence of $\mathrm{L}$-propranolol. The radioligand dissociation constant $\left(K_{\mathrm{D}}\right)$ and the density of ICYP binding sites $\left(B_{\max }\right)$ were determined by Scatchard plot analysis (28). $\beta$-Receptor density was expressed in femtomoles per milligram of membrane protein (9).

Validation of methodology. To validate the ICYP binding assay for ovine myocardium, we performed several preliminary studies. ICYP specific binding was found to be stereospecific for competition by the $(-)$ isomer vs. the $(+)$ isomer of isoproterenol. The rank order of potency for various agonists was $(-)$ isoproterenol $>$ epinephrine $=$ norepinephrine, the expected order of potency for a $\beta$-receptor population. Determination of onset kinetics showed that a steady state was achieved at $45 \mathrm{~min}(n=2)$. The $K_{\mathrm{D}}$ determined from the kinetic data $\left(k_{2} / k_{1}\right)$ was $45 \pm 8 \mathrm{pM}$, similar to that obtained in the steady-state system on the same tissue samples $(n=2)$. Protein analysis by the Lowry method demonstrated protein concentrations of between 113.6 and $378.5 \mu \mathrm{g} / \mathrm{ml}$, or $34.1-113.6 \mu \mathrm{g}$ of protein per assay vial. Specifically bound ICYP was determined to be linearly related to protein concentration in this range. Specific binding was saturable and $>70 \%$ of total binding at an ICYP concentration of $100 \mathrm{pM}$.

To determine that the observed change in receptor density was not an artifactual one secondary to alterations in membrane protein content, the activity of plasma membrane-associated 5'-nucleotidase was determined by the method of Arkesteijn $(29,30)$. 5'-nucleotidase activity was assayed utilizing a coupled reaction and determining the rate of formation of NAD+ from NADH by measuring the change in absorbance at $340 \mu \mathrm{m}$.

$\beta$-Adrenergic receptor agonist binding. Agonist competition for ICYP was performed according to the method of Vatner et al. (17). Membranes were initially washed in magnesium-free buffer $(100 \mathrm{mM}$ Tris, $10 \mathrm{mM}$ EDTA, $\mathrm{pH} 7.2$ ) and centrifuged at $45,000 \mathrm{~g}$ for $15 \mathrm{~min}$. The pellet was then resuspended in magnesium-containing buffer $(100$ $\mathrm{mM}$ Tris, $5 \mathrm{mM} \mathrm{MgCl}, 1 \mathrm{mM}$ EDTA, $\mathrm{pH}$ 7.2) and incubated with 100 pM ICYP and 16 concentrations of isoproterenol $\left(10^{-4}\right.$ to $\left.10^{-9} \mathrm{M}\right)$ prepared in $0.1 \mathrm{mM}$ ascorbic acid, both in the presence and absence of $0.1 \mathrm{mM} \mathrm{Gpp}(\mathrm{NH})$ p. Agonist competition curves were fitted to both one- and two-site models utilizing a microcomputer-based modification of the program "Ligand" (Biosoft, Cambridge, UK) and the quality of the fits compared by $\mathrm{F}$ test.

Adenylate cyclase activity. Catecholamine and maximally stimulated adenylate cyclase activities were determined by a modification of the method of Salomon et al. $(9,31) .0 .2 \mathrm{~g}$ of tissue was weighed and placed in 25 vol of iced buffer ( $250 \mathrm{mM}$ sucrose, $5 \mathrm{mM}$ Tris, $1 \mathrm{mM}$ EGTA, pH 7.45), minced, and homogenized with a Polytron. The homogenate was centrifuged at $1,085 \mathrm{~g}$ for $20 \mathrm{~min}$. Resuspension and centrifugation of the pellet was repeated three times. The final resuspension was filtered through a 25-gauge needle and brought to a final volume of $12 \mathrm{ml}$ (protein concentration of $5-12 \mathrm{mg} / \mathrm{ml}$ ). A volume of the homogenate was then added to the reagent mixture $(50 \mathrm{mM}$ TrisBase at pH 7.5, $0.1 \mathrm{mg} / \mathrm{ml} \mathrm{BSA,} 1.0 \mathrm{mM}$ cAMP, $0.1 \mathrm{mM}$ ATP, $0.5 \mathrm{mM}$ 
$\mathrm{MgCl}_{2}, 5.0 \mathrm{mM}$ phosphocreatine, and $50 \mathrm{U} / \mathrm{ml}$ creatine kinase). Stimulation of adenylate cyclase activity was achieved by adding one of the following to the reaction mixturewaried concentrations of isoproterenol $\left(10^{-4}\right.$ to $\left.10^{-8} \mathrm{M}\right), 10 \mathrm{mM}$ sodium fluoride, $0.01 \mathrm{mM}$ forskolin, 0.1 $\mathrm{mM}$ Gpp(NH)p, or $0.1 \mathrm{mM}$ isoproterenol plus $0.1 \mathrm{mM} \mathrm{Gpp(NH)p}$. $\left[\alpha-{ }^{32}\right.$ P]ATP (New England Nuclear, pH 7.45) was then added to yield a volume of $50 \mu \mathrm{l}$ and the tubes were incubated at $30^{\circ} \mathrm{C}$ for $25 \mathrm{~min}$. The assay was stopped by the addition of $700 \mu$ l of $\left[{ }^{3} \mathrm{H}\right]$ AMP (New England Nuclear) in $0.325 \mathrm{~N} \mathrm{HCl}$ and the tubes were frozen in dry ice and ethanol and then boiled for $3 \mathrm{~min}$. $\left.{ }^{32} \mathrm{P}\right] \mathrm{cAMP}$ was then isolated via chromatography over alumina columns according to a modification of the method of Salomon et al. (31). Protein was assayed by the method of Lowry et al. (27). Basal cAMP generation, maximal catecholamine-stimulated cAMP generation, and sodium fluoride, $\mathrm{Gpp}(\mathrm{NH}) \mathrm{p}$, and forskolin-stimulated cAMP generation were thus determined. The concentration of isoproterenol stimulating $50 \%$ maximal cAMP generation $\left(\mathrm{EC}_{50}\right)$ was determined by regression analysis.

Catecholamine and thyroid hormone assays. Blood samples were obtained after two weeks of hypoxemia in the experimental group and at four weeks of age in the controls with the lambs resting quietly in a sling in a temperature controlled room. For measurement of circulating catecholamines, plasma was collected in EGTA and glutathione. Tissue samples for norepinephrine levels were taken from the midleft ventricular free wall and frozen at $-70^{\circ} \mathrm{C}$ until assayed. Tissues were homogenized in $0.4 \mathrm{~N}$ perchloric acid buffer containing $5 \mathrm{mM}$ reduced glutathione, centrifuged at $16,000 \mathrm{~g}$ at $0^{\circ} \mathrm{C}$ for $20 \mathrm{~min}$, and the supernatant diluted 1:50. Norepinephrine (serum and tissue) and epinephrine (serum) were converted to their meta- $\left[{ }^{3} \mathrm{H}\right]$ methoxy derivatives by catechol-O-methyltransferase (COMT) in the presence of S-adenosyl$\mathrm{L}-\left[\right.$ methyl $\left.-{ }^{3} \mathrm{H}\right]$ methionine, extracted, and separated by thin-layer chromatography. The isolated derivatives $\left[{ }^{3} \mathrm{H}\right]$ normetanephrine and $\left[{ }^{3} \mathrm{H}\right]-$ metanephrine were converted by periodate oxidation to $\left[{ }^{3} \mathrm{H}\right]$ vanillin, extracted, and radioactivity determined by liquid scintillation counting (Cat-a-Kit, Amersham Corp., Arlington Heights, IL). Serum was also obtained for measurement of thyroid hormones. Triiodothyronine $\left(T_{3}\right)$ was assayed by competitive radioimmunoassay using [ $\left.{ }^{125} \mathrm{I}\right]-$ triiodothyronine tracer (Gammacoat $\left[{ }^{125} \mathrm{I}\right] \mathrm{T}_{3}$ radioimmunoassay kit, Baxter Travenol, Cambridge, MA.). Free thyroxine (Free $\mathrm{T}_{4}$ ) was assayed by competitive radioimmunoassay using ${ }^{125} \mathrm{I}$-free thyroxine tracer (Gammacoat ${ }^{125}$ I-Free T4 Direct One-Step Radioimmunoassay, Baxter Travenol). Standard curves for thyroid hormones were prepared using both human and ovine serum standards (Baxter Travenol).

Analysis. Data were compared between the nine hypoxemic and eight control lambs using the Mann-Whitney test. Statistical significance was considered achieved when $P$ was $<0.05$. Results in figures and in the text are expressed as mean $\pm 1 \mathrm{SE}$.

\section{Results}

General. There was no difference in age at sacrifice between the nine hypoxemic and eight control lambs (Table I). The hypoxemic lambs weighed less than the controls, although this difference did not reach statistical significance. Growth rate, however, was significantly less in the hypoxemic lambs, a consequence of chronic hypoxemia previously described in this model (3). Although aortic oxygen saturation was decreased by $24 \%$ in the hypoxemic lambs compared to the controls, hemoglobin concentration was increased, so that aortic oxygen content was decreased by only $14 \%$ (Table I).

Heart weights. Total heart weight and right ventricular free wall weight were markedly increased (by $55 \%$ and $89 \%$, respectively) in the hypoxemic lambs compared with the controls (Fig. 1). Left ventricular free wall weight was identical to that in the controls, so that the right to left ventricular free wall weight ratio increased by $76 \%$.
Table I. Characteristics of Hypoxemic and Control Lambs at Termination of Study

\begin{tabular}{lrr}
\hline & Hypoxemic & \multicolumn{1}{c}{ Control } \\
\hline Age $(d)$ & $25.0 \pm 1.3$ & $25.0 \pm 1.6$ \\
Weight $(\mathrm{kg})$ & $7.5 \pm 0.5$ & $9.0 \pm 0.7$ \\
Aortic $\mathrm{O}_{2}$ saturation $(\%)$ & $74.6 \pm 1.8^{*}$ & $98.8 \pm 0.6$ \\
Hemoglobin $(\mathrm{g} / \mathrm{dl})$ & $13.0 \pm 0.5^{\ddagger}$ & $11.4 \pm 0.3$ \\
Aortic $\mathrm{O}_{2}$ content $(\mathrm{ml} / \mathrm{dl})$ & $13.2 \pm 0.6^{\S}$ & $15.3 \pm 0.4$ \\
\hline
\end{tabular}

${ }^{*} P<0.001 .{ }^{\ddagger} P=0.05 .{ }^{\S} P<0.05$ by Mann-Whitney test.

$\beta$-Adrenergic receptor density. During chronic hypoxemia $\beta$-receptor density $\left(B_{\max }\right)$ was decreased by $45 \%$ in the left ventricle (exposed to hypoxemia alone) but was unchanged in the right ventricle (exposed to hypoxemia and pressure overload) (Fig. $2 A$ ). $\beta$-Receptor ligand affinities $\left(K_{\mathrm{D}}\right)$ for both right and left ventricles were unchanged from control (Fig. $2 B$ ). Saturation binding isotherms showing the mean derived specific binding for both hypoxemic and control lambs are shown in Fig. $3 A$. The decreased $\beta$-adrenergic receptor density of the hypoxemic left ventricle is readily apparent from the difference in maximal height of the two curves. A Scatchard plot of the same data is shown in Fig. 3 B. Plasma membrane associated 5 '-nucleotidase activity in the hypoxemic membrane preparations was not different from control for either the left ventricle (hypoxemic, $42.0 \pm 6.7$ vs. control, $52.5 \pm 7.7 \mathrm{mIU} / \mathrm{mg}$ protein, NS) or the right ventricle $(45.0 \pm 4.2$ vs. $47.4 \pm 5.6$ $\mathrm{mIU} / \mathrm{mg}$ protein, NS). Thus, the change in receptor density was not an artifact secondary to differences in the membrane preparation.

$\beta$-Adrenergic receptor agonist binding. Isoproterenol competition curves in the absence of $\mathrm{Gpp}(\mathrm{NH}) \mathrm{p}$ were best described by a two-site model for both the hypoxemic and control lambs. Both the $K_{\mathrm{H}}$ of the high-affinity site (hypoxemic, $1.21 \pm 1.17 \times 10^{11}$ vs. control, $1.29 \pm 0.93 \times 10^{10}$ ) and the $K_{\mathrm{L}}$ for the low-affinity site (hypoxemic, $3.73 \pm 0.58 \times 10^{6}$ vs. control, $3.69 \pm 0.58 \times 10^{6}$ ) were not significantly different between the two groups of lambs. The percentages of high-affinity (hypoxemic, $41 \pm 5 \%$ vs. control, $38 \pm 4 \%)$ and low-affinity ( $59 \pm 5 \%$ vs. $62 \pm 4 \%$ ) receptor sites were also not different between the two groups. Finally, there was no significant difference between the hypoxemic and control lambs in the shift to the right of the agonist binding curve induced by the addition of $\mathrm{Gpp}(\mathrm{NH}) \mathrm{p}$. Isoproterenol competition curves in the presence of $\mathrm{Gpp}(\mathrm{NH}) \mathrm{p}$ were best described by a one-site model with an

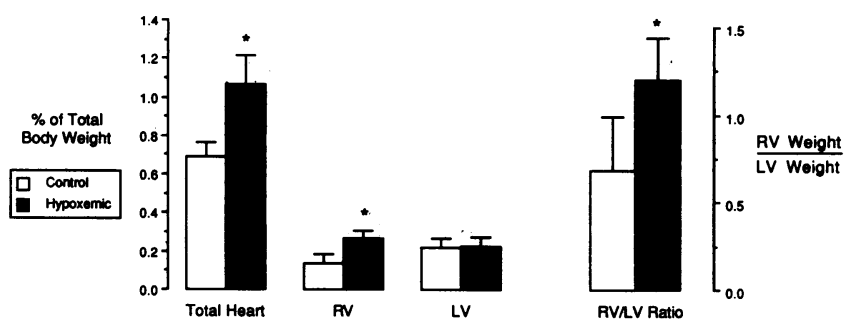

Figure 1. Effect of chronic hypoxemia on total heart weight and right and left ventricular free wall weights. To correct for differences in animal sizes, heart weights are expressed as a percentage of total body weight. $\left({ }^{*} P<0.05\right.$ by two-tailed Mann-Whitney test). 

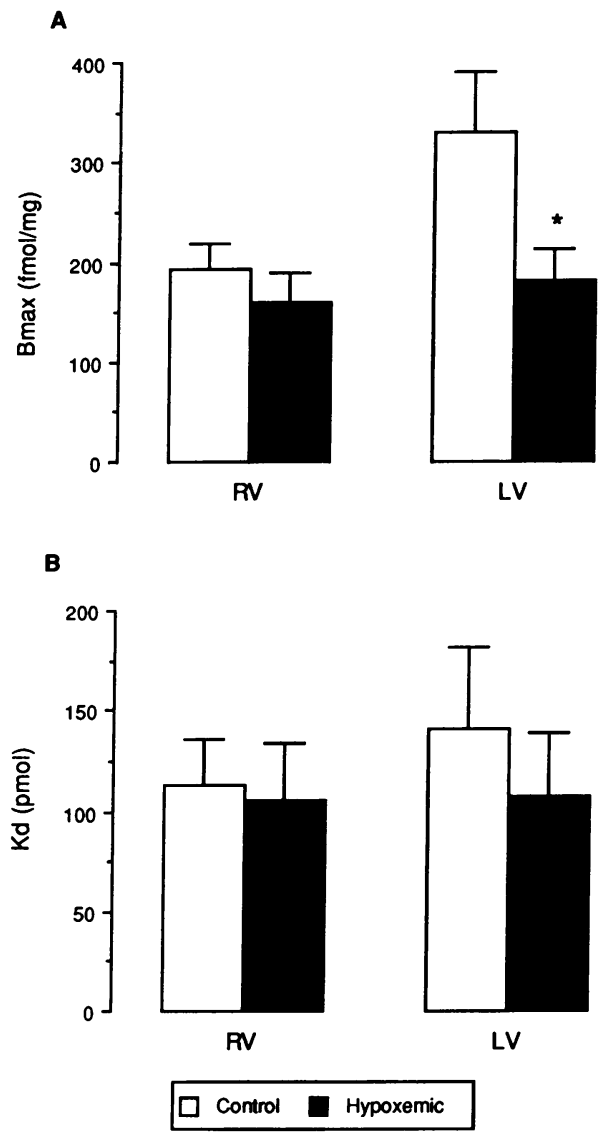

Figure 2. (A) Effect of chronic hypoxemia on right and left ventricular $\beta$-adrenergic receptor density $\left(B_{\max }\right)$ and $(B)$ ligand affinity $\left(K_{\mathrm{D}}\right)$. $\left({ }^{*} P<0.05\right.$ by two-tailed Mann-Whitney test).

affinity constant $K_{\mathrm{L}}$ of $3.24 \pm 0.36 \times 10^{6}$ in the hypoxemic lambs and $3.20 \pm 0.42 \times 10^{6}$ in the controls (NS by the MannWhitney test).

Adenylate cyclase activity. In the left ventricles of the hypoxemic lambs maximal isoproterenol stimulated adenylate cyclase activity was decreased by $39 \%$ (Fig. $4 \mathrm{~A}$ ), whereas sodium fluoride and forskolin activities were not different from control. The $\mathrm{EC}_{50}$ for isoproterenol stimulation of adenylate cyclase was $9.6 \pm 5.1 \times 10^{-7}$ in the hypoxemic lambs and $4.8 \pm 2.0 \times 10^{-7}$ in the controls (NS by the Mann-Whitney test). In contrast, in the right ventricles of the hypoxemic lambs, maximal isoproterenol, sodium fluoride and forskolin stimulated adenylate cyclase activities were all not significantly different from control (Fig. $4 \mathrm{~B}$ ).

Catecholamines and thyroid hormones. Plasma levels of epinephrine were increased nearly fourfold in the hypoxemic lambs whereas norepinephrine levels were not significantly different from control (Fig. 5). Left ventricular tissue levels of norepinephrine, expressed either per mg of tissue or per total left ventricular free wall, were not significantly different from control (Fig. 5). Serum levels of $T_{3}$ and free $T_{4}$ in the hypoxemic lambs were also not different from control (Fig. 6).

\section{Discussion}

Sympathetic regulation of myocardial performance, modulated by the $\beta$-adrenergic receptor/adenylate cyclase system,
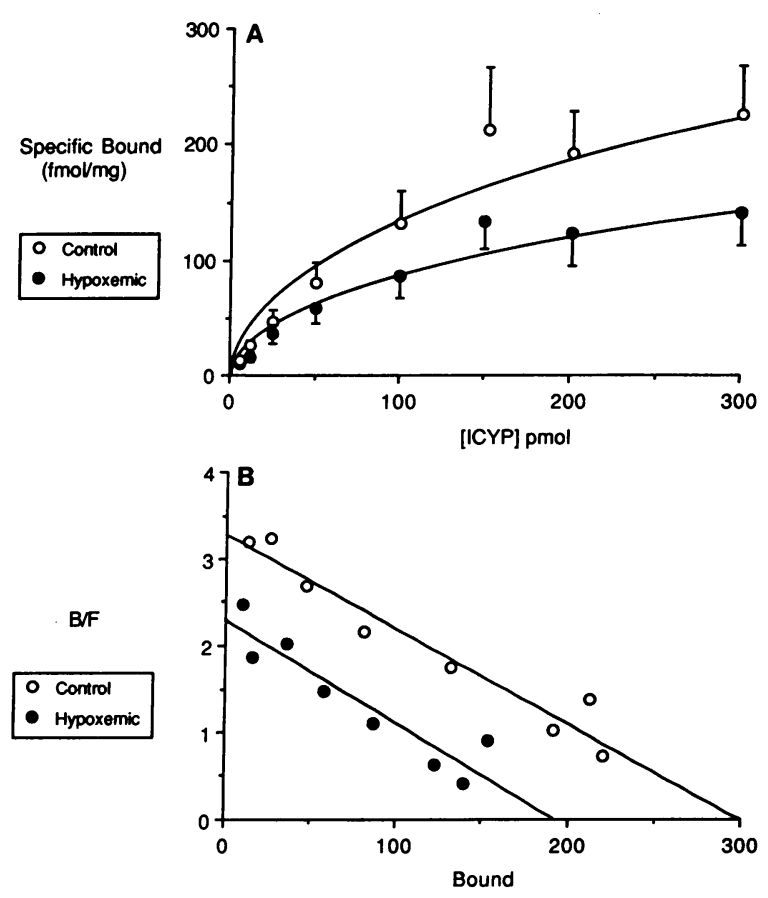

Figure 3. (A) Radioligand binding isotherms showing the mean and $1 \mathrm{SE}$ of the derived specific binding from hypoxemic and control lambs. The decreased $\beta$-adrenergic receptor density of the hypoxemic left ventricles is readily apparent from the difference in the maximal height of the two curves. ( $B$ ) Scatchard plots of the data in $A$. $\beta$-receptor density $\left(B_{\max }\right)$ is determined from the $x$-intercept and ligand affinity $\left(K_{D}\right)$ from the negative inverse of the slope. The decrease in $\beta$-receptor density of the hypoxemic left ventricles compared to the controls is again readily visualized.

has been shown to be altered during various acute and chronic hemodynamic derangements, such as congestive heart failure $(9,10)$, pressure overload hypertrophy (17), myocardial in-
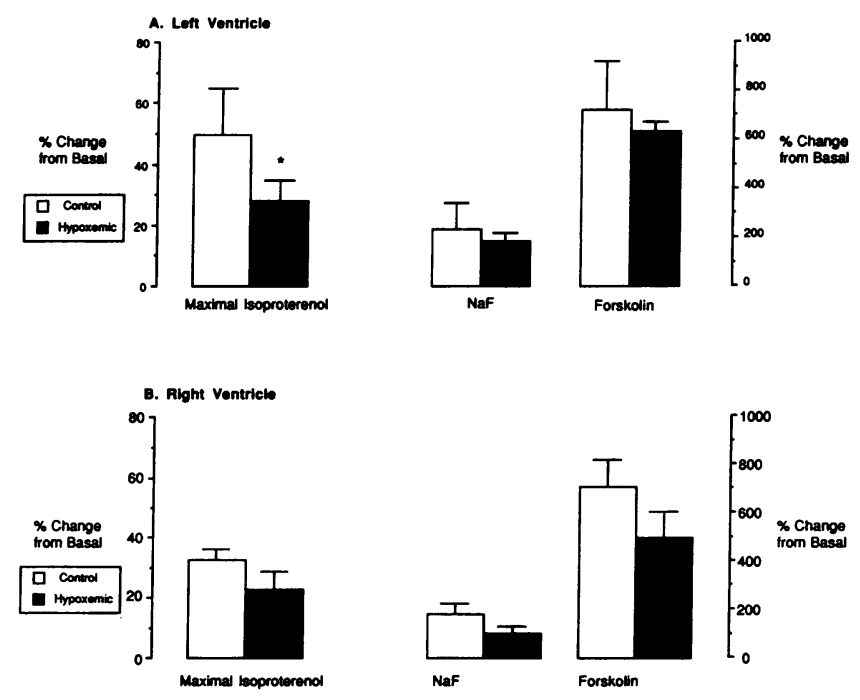

Figure 4. (A) Effect of chronic hypoxemia on left ventricular adenylate cyclase activity. Percent change from basal activity is shown during stimulation with isoproterenol, $\mathrm{NaF}$, and forskolin. Note the difference in the $y$-axis scales for isoproterenol vs. $\mathrm{NaF}$ and forskolin. $(B)$ Effect of chronic hypoxemia on right ventricular adenylate cyclase activity. $\left({ }^{*} P<0.05\right.$ by one-tailed Mann-Whitney test). 


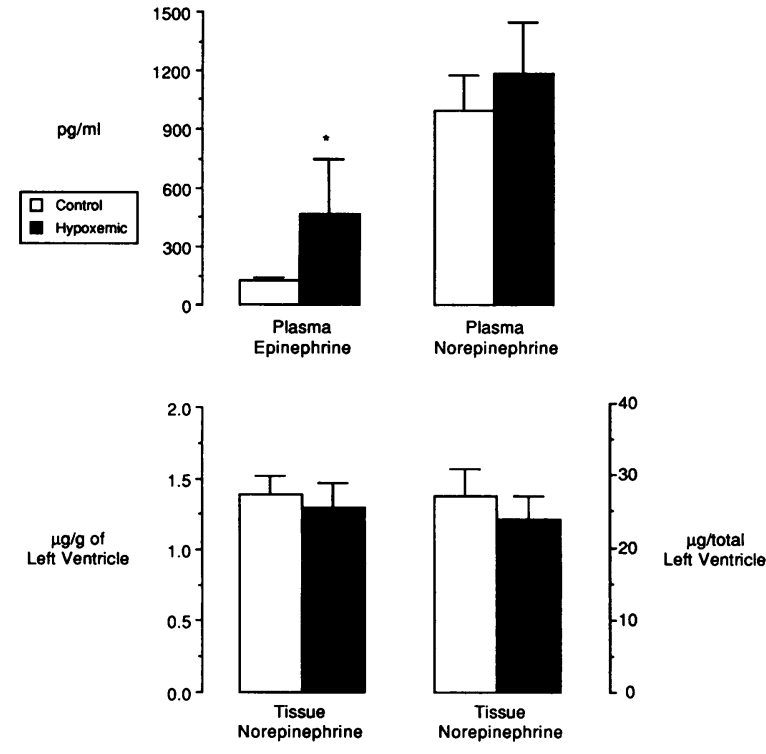

Figure 5. Effect of chronic hypoxemia on plasma levels of epinephrine and plasma and myocardial tissue levels of norepinephrine. ( ${ }^{*} P<0.05$ by two-tailed Mann-Whitney test).

farction $(32,33)$, and after cardiac denervation (30). The current study demonstrates a down-regulation of the left ventricular $\beta$-adrenergic receptor/adenylate cyclase system in the newborn lamb with chronic hypoxemia secondary to an intracardiac right-to-left shunt. Despite a $45 \%$ decrease in left ventricular $\beta$-receptor density, $\beta$-receptor-ligand affinity and the distribution between high- and low-affinity binding sites were unchanged. These data in the newborn lamb are consistent with the results of previous studies during chronic alveolar hypoxemia in adult animals of lower species. Exposure of rats to a simulated altitude of $4,250 \mathrm{~m}$ for $5 \mathrm{wk}$ resulted in a decrease in $\beta$-receptor density, no change in affinity, and a decrease in isoproterenol-stimulated adenylate cyclase activity (13). Exposure of guinea pigs to a slightly higher altitude $(6,000$ $\mathrm{m})$ resulted in a decrease in $\beta$-receptor density with an increase in affinity (14). In a third study, however, rats exposed to $10 \%$ oxygen for 4 wk showed no significant change in myocardial $\beta$-receptor density (15). The results of the current study are of potential clinical significance because they have been described for the first time in a model of chronic hypoxemia which approximates the physiologic derangements present in infants and children with cyanotic congenital heart disease.

In contrast to the left ventricle, exposed to chronic hypoxemia alone, $\beta$-adrenergic receptor density in the right ventricle, exposed to both chronic hypoxemia and chronic pressure
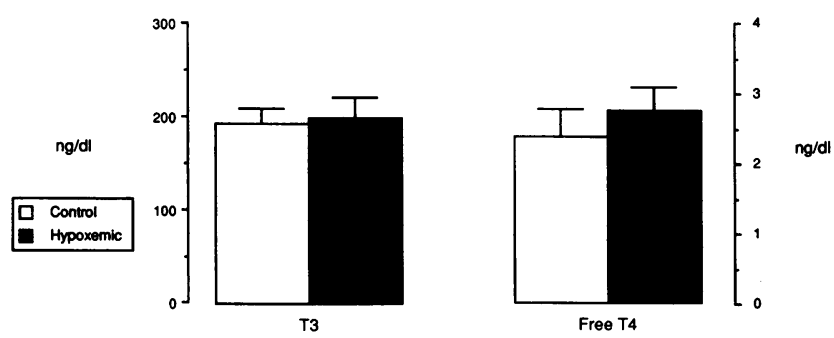

Figure 6. Effect of chronic hypoxemia on thyroid hormone levels. overload, was not different from control. This stands in contrast to the results of Vatner and co-workers (34), who have demonstrated an increase in $\beta$-receptor density in hypertrophied left ventricles from aortic banded dogs. This discrepancy may be related to the shorter time course of our study, to a difference in the response of the systemic versus the pulmonary or the newborn versus the adult ventricle to chronic pressure overload, or to a balance between the down-regulating influence of chronic hypoxemia and the up-regulating influence of pressure overload.

The physiologic significance of the $\beta$-receptor down-regulation we have described may be attenuated either by the presence of spare receptors (35) or the potential for amplification within the guanyl nucleotide stimulatory protein-adenylate cyclase system (36). Down-regulation of the $\beta$-receptor/adenylate cyclase system may be associated only with decreased cell surface receptor density (homologous desensitization) (37), or with a generalized refractoriness to stimulation of adenylate cyclase activity (heterologous desensitization) $(38,39)$. In the present study, the decrease in left ventricular $\beta$-receptor density was associated with a comparable decrease in isoproterenol-stimulated adenylate cyclase activity. However, direct stimulation of adenylate cyclase activity by sodium fluoride or forskolin was not different from control. The response to these agents, which stimulate adenylate cyclase activity independent of the $\beta$-adrenergic receptor, suggests that the down-regulation produced by chronic hypoxemia is one of homologous desensitization and that the activity of the guanyl nucleotide stimulatory protein is not significantly altered during chronic hypoxemia. Although the agonist-response curve was shifted slightly to the right during chronic hypoxemia, this difference did not reach statistical significance, suggesting the absence of a significant attenuation by spare $\beta$-adrenergic receptors.

This study also demonstrates that chronic hypoxemia secondary to an intracardiac right-to-left shunt is associated with a persistent increase in sympathetic stimulation. This increase in sympathetic activity is mediated by an increased level of circulating epinephrine. There is, however, no evidence for a chronic increase in neural stimulation, as determined by the absence of an alteration in myocardial norepinephrine stores (17). The increase in circulating catecholamines in the hypoxemic lambs is consistent with previous studies during both acute $(21,40)$ and chronic hypoxemia $(4,21)$. The down-regulating effect of increased circulating catecholamines on the myocardial $\beta$-adrenergic receptor has been previously well documented $(6,41,42)$ and we hypothesize this as a potential mechanism for the down-regulation in our lambs. Conversely, alterations in thyroid hormone status, which have been shown to affect $\beta$-receptor density in the newborn (43), were not a factor in the present study. Although several studies have described hypothyroidism in chronically hypoxemic newborns $(22,23,44)$, others, including the present study, have failed to confirm these findings (45). An additional mechanism which could have accounted for the decrease in sarcolemmal $\beta$-receptor density would be an alteration in the intracellular processing of the $\beta$-receptor after ligand interaction, leading to an increase in the fraction of internalized receptors. The relative contribution of this potential mechanism, which would be opposite to that which occurs during myocardial ischemia (33), was not addressed in the present study.

In summary, we have demonstrated a down-regulation of the left ventricular $\beta$-adrenergic receptor/adenylate cyclase 
system in newborn lambs with chronic hypoxemia secondary to an intracardiac right-to-left shunt. This down-regulation is associated with an increase in myocardial sympathetic stimulation mediated by circulating catecholamines. We speculate that this down-regulation may contribute to the decreased left ventricular performance seen in patients with cyanotic congenital heart disease $(11,12)$, although further studies must be performed to confirm in vivo significance. Failure of the right ventricular $\beta$-adrenergic receptor to up-regulate in response to an afterload stress when coupled with hypoxemia may similarly affect right ventricular function in those patients with cyanotic heart disease who also have right ventricular outflow tract obstruction.

\section{Acknowledgments}

The authors are grateful for the support and assistance of Drs. Jeffrey Andresen, Brian B. Hoffman, Michael B. Fowler, and Abraham M. Rudolph.

This work was supported by a National Institutes of Health FIRST Award (HL-38741) and a National Institutes of Health BRSG Award (RR 05353-15). Mr. Doshi was the recipient of an American Heart Association Medical Student Research Fellowship.

\section{References}

1. Downing, S. E., T. H. Gardner, and J. M. Rocamora. 1969. Adrenergic support of cardiac function during hypoxia in the newborn lamb. Am. J. Physiol. 217:728-735.

2. Sidi, D., D. F. Teitel, J. R. G. Kuipers, M. A. Heymann, and A. M. Rudolph. 1988. Effects of beta adrenergic blockade on response to acute hypoxemia in newborn lambs. Pediatr. Res. 23:229-234.

3. Teitel, D. F., D. Sidi, D. Bernstein, M. A. Heymann, and A. M. Rudolph. 1985. Chronic hypoxemia in the newborn lamb: cardiovascular, hematopoietic, and growth adaptations. Pediatr. Res. 19:10041010.

4. Maher, J. T., S. C. Manchanda, A. Cymerman, D. L. Wolfe, and L. H. Hartley. 1975. Cardiovascular responsiveness to $\beta$-adrenergic stimulation and blockade in chronic hypoxia. Am. J. Physiol. 228:477-481.

5. Bernstein, D., D. F. Teitel, D. Sidi, M. A. Heymann, and A. M. Rudolph. 1987. Redistribution of regional blood flow and oxygen delivery in experimental cyanotic congenital heart disease. Pediatr. Res. 22:389-393.

6. Tse, J., J. R. Powell, C. A. Baste, R. E. Priest, and J. F. Kuo. 1979. Isoproterenol-induced cardiac hypertrophy: modifications in characters of beta-adrenergic receptor, adenylate cyclase, and ventricular contraction. Endocrinology. 105:246-255.

7. Baumann, G., G. Riess, and W. D. Erhardt. 1981. Impaired beta-adrenergic stimulation in the uninvolved ventricle post-acute myocardial infarction: reversible defect due to excessive circulating catecholamine-induced decline in number and affinity of beta-receptors. Am. Heart J. 101:569-581.

8. Laks, M. M., F. Morady, and A. J. C. Swan. 1973. Myocardial hypertrophy produced by chronic infusion of subhypertensive doses of norepinephrine in the dog. Chest. 64:75-78.

9. Bristow, M. R., R. Ginsburg, W. Minobe, R. S. Cubicciotti, W. S. Sageman, K. Lurie, M. E. Billingham, D. C. Harrison, and E. B. Stinson. 1982. Decreased catecholamine sensitivity and $\beta$-adrenergicreceptor density in failing human hearts. $N$. Engl. J. Med. 307:205211.

10. Fowler, M. B., J. A. Laser, G. L. Hopkins, W. Minobe, and M. R. Bristow. 1986. Assessment of the $\beta$-adrenergic receptor pathway in the intact failing human heart: progressive receptor down-regulation and subsensitivity to agonist response. Circulation. 74:1290-1302.

11. Graham, T. P., H. G. Erath, R. J. Boucek, R. C. Boerth. 1980. Left ventricular function in cyanotic congenital heart disease. Am. J. Cardiol. 45:1231-1236.
12. Jarmakani, J. M., T. P. Graham, R. V. Cevent, and P. H. Jewett. 1972. Left heart function in children with tetralogy of Fallot before and after palliative or corrective surgery. Circulation. 46:478490.

13. Voelkel, N. F., L. Hegstrand, J. T. Reeves, I. F. McMurty, and P. B. Molinoff. 1981. Effects of hypoxia on density of $\beta$-adrenergic receptors. J. Appl. Physiol. 50:363-366.

14. Light, K. E., T. E. Dick, and M. J. Hughes. 1984. Central and peripheral receptors in guinea-pigs exposed to simulated high altitude. Neuropharmacology. 23:189-195.

15. Winter, R. J. D., K. E. J. Dickinson, R. M. Rudd, and P. S. Sever. 1986. Tissue specific modulation of $\beta$-adrenoceptor number in rats with chronic hypoxia with an attenuated response to down-regulation by salbutamol. Clin. Sci. (Lond.) 70:159-165.

16. Lister, G., and B. R. Pitt. 1983. Cardiopulmonary interactions in the infant with congenital cardiac disease. Clin. Chest Med. 4:219232.

17. Vatner, D. E., S. F. Vatner, A. M. Fujii, and C. J. Homcy. 1985. Loss of high affinity cardiac beta adrenergic receptors in dogs with heart failure. J. Clin. Invest. 76:2259-2264.

18. Jarmakani, J. M., M. Nakazawa, T. Nagatomo, and G. A. Langer. 1978. Effect of hypoxia on mechanical function in the neonatal mammalian heart. Am. J. Physiol. 235:H469-H474.

19. Rockson, S. G., C. J. Homcy, P. Quinn, W. T. Manders, E. Haber, and S. F. Vatner. 1981. Cellular mechanisms of impaired adrenergic responsiveness in neonatal dogs. J. Clin. Invest. 67:319327.

20. Whitset, J. A., and C. Darovec-Beckerman. 1981. $\beta$ adrenergic and adenylate cyclase in developing rat myocardium. Pediatr. Res. 15:475. (Abstr.)

21. Hedner, T., B. Bergman, and M. Holmgren. 1980. Adrenal catecholamines during and following hypoxia in neonatal rats. Med. Biol. 58:228-231.

22. Redding, R. A., and C. Pereria. 1974. Thyroid function in respiratory distress syndrome (RDS) of the newborn. Pediatrics. 54:423-428.

23. Moshang, T., K. H. Chance, M. M. Kaplan, R. D. Utiger, and O. Takahashi. 1980. Effects of hypoxia on thyroid function tests. $J$. Pediatr. 97:602-604.

24. Bernstein, D., J. G. Bell, R. O. Castillo, L. Kwong, and R. L. Hintz. 1989. Mechanisms of growth failure in experimental cyanotic heart disease. Pediatr. Res. 25:21A. (Abstr.)

25. Cuatrecasas, P., and M. D. Hollenberg. 1976. Membrane receptors and hormone action. Adv. Protein Chem. 30:251-451.

26. Hollenberg, M. D., and P. Cuatrecasas. 1979. Distinction of receptor from nonreceptor interactions in binding studies. In The Receptors. R. D. O'Brien, editor. Plenum Press, New York. 193-213.

27. Lowry, O. H., N. J. Rosebrough, A. L. Farr, and R. J. Randall. 1951. Protein measurement with the Folin phenol reagent. J. Biol. Chem. 193:265-275.

28. Scatchard, G. 1949. The attractions of proteins for small molecules and ions. Ann. N.Y. Acad. Sci. 51:660-672.

29. Arkesteijn, C. L. M. 1976. A kinetic method for serum 5'-Nucleotidase using stabilised glutamate dehydrogenase. J. Clin. Chem. Clin. Biochem. 14:155-158.

30. Vatner, D. E., M. Lavallee, J. Amano, A. Finizola, C. J. Homcy, and S. F. Vatner. 1985. Mechanisms of supersensitivity to sympathomimetic amines in the chronically denervated heart of the conscious dog. Circ. Res. 57:55-57.

31. Salomon, Y., C. Londos, and M. Rodbell. 1974. A highly sensitive adenylate cyclase assay. Anal. Biochem. 58:541-548.

32. Mukherjee, A., T. M. Wong, M. Buja, R. J. Lefkowitz, and J. T. Willerson. 1979. Beta adrenergic and muscarinic cholinergic receptors in canine myocardium: effects of ischemia. J. Clin. Invest. 64:14231428.

33. Maisel, A. S., H. J. Motulsky, and P. A. Insel. 1985. Externalization of $\beta$-adrenergic receptors promoted by myocardial ischemia. Science (Wash. DC). 230:183-186. 
34. Vatner, D. E., C. J. Homcy, S. P. Sit, W. T. Manders, and S. F. Vatner. 1984. Effects of pressure overload left ventricular hypertrophy on beta-adrenergic receptors and responsiveness to catecholamines. $J$. Clin. Invest. 73:1473-1482.

35. Venter, J. C. 1979. High efficiency coupling between betaadrenergic receptors and cardiac contractility: direct evidence for "spare" beta-adrenergic receptors. Mol. Pharmacol. 16:429-440.

36. Alberts, B., D. Bray, J. Lewis, M. Raff, K. Roberts, and J. D. Watson. 1983. Molecular Biology of the Cell. Garland Publishing, New York. 750 pp.

37. Sibley, D. R., R. H. Strasser, M. G. Caron, and R. J. Lefkowitz. 1985. Homologous desensitization of adenylate cyclase is associated with phosphorylation of the beta-adrenergic receptor. J. Biol. Chem. 260:3883-3886.

38. Stadel, J. M., A. DeLean, D. D. Mullikin-Kilpatrick, D. O. Sawyer, and R. J. Lefkowitz. 1981. Catecholamine-induced desensitization in turkey erythrocytes: cAMP-mediated impairment of high affinity agonist binding alteration in receptor number. $\mathrm{J}$. Cyclic $\mathrm{Nu}$ cleotide Res. 7:37-47.

39. Stadel, J. M., P. Nambi, R. G. L. Shorr, D. F. Sawyer, M. G. Caron, and R. J. Lefkowitz. 1983. Catecholamine-induced desensitization of turkey erythrocyte adenylate cyclase is associated with phos- phorylation of the beta-adrenergic receptor. Proc. Natl. Acad. Sci. USA. 80:3173-3177.

40. Cunningham, W. L., E. J. Becker, and F. Kreuzer. 1965. Catecholamines in plasma and urine at high altitude. J. Appl. Physiol. 20:607-610.

41. Shenkman, L., M. Saito, F. Feh, and M. Goldstein. 1979. Reduced number of cardiac beta-adrenergic receptors in rat pheochromocytoma. Clin. Res. 27:595A. (Abstr.)

42. Snavely, M. D., L. C. Mahan, D. T. O'Connor, P. A. Insel. 1983. Selective down-regulation of adrenergic receptor subtypes in tissues from rats with pheochromocytoma. Endocrinology. 113:354361 .

43. Padbury, J. F., A. H. Klein, D. H. Polk, R. W. Lam, C. Hobel, and D. A. Fisher. 1986. Effect of thyroid status on lung and heart beta-adrenergic receptors in fetal and newborn sheep. Dev. Pharmacol. Ther. 9:44-53.

44. Uhrmann, S., K. H. Marks, M. J. Maisels, Z. Friedman, F. Murray, H. Kulin, M. Kaplan, and R. Utiger. 1978. Thyroid function in the preterm infant: a longitudinal assessment. J. Pediatr. 92:968973.

45. Klein, A. H., B. Foley, T. P. Foley, H. M. MacDonald, and D. A. Fisher. 1981. Thyroid function studies in cord blood from premature infants with and without RDS. J. Pediatr. 98:818-820. 